\title{
Genetic Variability, Heritability, Genetic Advance and Divergence for Yield and Its Contributing Traits in Faba bean (Vicia faba L.)
}

\author{
Amit Kumar Chaudhary ${ }^{*}$, C. B. Yadav, Hamsa Poorna Prakash, \\ Shiv Prakash Shrivastav and Suraj Kumar Hitaishi
}

Department of Genetics and Plant Breeding, Narendra Deva University of Agriculture and Technology, Narendra Nagar Kumarganj, Faizabad-224-229 (Uttar Pradesh), India

*Corresponding author

\section{A B S T R A C T}

\begin{tabular}{|l|}
\hline Ke y w o r d s \\
$\begin{array}{l}\text { Faba bean, genetic } \\
\text { variability, genetic } \\
\text { advance, heritability, } \\
\text { divergence and seed yield }\end{array}$ \\
\hline Article Info \\
\hline $\begin{array}{l}\text { Accepted: } \\
\text { 15 May 2018 } \\
\text { Available Online: } \\
\text { 10 June 2018 }\end{array}$ \\
\hline \hline
\end{tabular}

Eighteen germplasm lines with two check varieties of Faba bean (Vicia faba L.) assessed to work out the genetic variability, heritability and genetic advance on different seed yield traits and divergence analysis of their various attributes on seed yield. The observations were recorded on eleven quantitative characters namely days to $50 \%$ flowering, days to maturity, plant height $(\mathrm{cm})$, number of branches per plant, number of pods per plant, number of seeds per pods, 100-seed weight $(\mathrm{g})$, biological yield per plant $(\mathrm{g})$, protein content $(\%)$, harvest index $(\%)$ and seed yield per plant $(\mathrm{g})$. The most promising lines showing highest seed yield with high mean performance for other yield contributing characters were identified as HB 11-38, HB 9-1 and NDFB 15-1. The non-hierarchical Euclidean cluster analysis grouped 18 genotypes in to five clusters. The highest number of genotypes appeared in cluster IV which contained 7 genotypes and cluster III was represented minimum number of genotypes. In this context maximum inter cluster distance was recorded between cluster II and cluster V. However, maximum intra-cluster distance was observed in cluster IV.

\section{Introduction}

Pulses are the second most important group of crops after cereals. Endowed with unique ability to trap atmospheric nitrogen in their root nodules in association with Rhizobium and thrive well under harsh and fragile ecosystem, pulses remained an integral component of subsistence farming system of dry land region since dawn of agriculture. Being a rich source of protein, minerals, vitamins and crude fibre, pulses are considered as health food and offer nutritional security to millions of population suffering with protein malnutrition especially in South Asia and Africa.

Globally, faba bean (Vicia faba L.), is third most important feed grain legume after soybean (Glycine max L.) and pea (Pisum sativum L.) with a total production of $4.87 \mathrm{MT}$ and in a harvested area of 2.63 million ha. China is currently the world's leading producer of faba bean with $60 \%$ of the total yield followed by northern Europe, Mediterranean, Ethiopia, central and East Asia 
and Latin America (FAO STAT, 2009). Faba bean is cultivated in different North Indian states. It is cultivated during winter (states of seasons) in plains and during rainy season $(R a b i)$ in hilly and mountainous region.

India is the largest producer and consumer of pulses in the world and also key player with 33 per cent. Pulses are grown in semi-arid region of India since time immemorial. Total pluses were grow on an area of 25.26 mha with production of $18.72 \mathrm{mt}$ and productivity of $762 \mathrm{~kg} / \mathrm{hawhile}$ area, production and productivity in Uttar Pradesh was 4.52 mha, $2.94 \mathrm{mt}$ and $843 \mathrm{~kg} /$ hectare, respectively (Anonymous, 2016). During the 1960s, the cultivation of faba bean (Vicia faba L.) became more popular in Finland. One of the main sources of earliness is the terminal inflorescence gene $(t i)$. With coordinated effort, faba bean could be cultivated in regions with a growing season of less than 100 days, and thus suitable for a broad scale at boreal zone in Europe, Asia and North America. Faba bean is generally recognized due to its rich nutritional value and has long history of its uses in human foods and animal feeds. Faba bean genotypes have a large genetic variability for starch, protein and fibre content.

Though the agronomic and economic importance of faba bean is well demonstrated, its cultivation is still limited due to different factors. Yield performance is often limited by the sensitivity of the crop to environmental conditions (especially cold and drought) and high susceptibility to diseases and pests. In addition to this, seeds of faba bean contain anti-nutritional compounds/factors that reduce their nutritional value. Faba bean contains small amounts of several anti-nutritional factors; however, their effects are less acute. The protease inhibitors remain in much lower (2\%) concentrations in comparison to soybeans (Lawes 1980, Bond et al., 1985). Roasted seeds are eaten like peanuts in India
(Duke 1981). Straw from faba bean harvest fetches a premium in Egypt and Sudan and is considered as a cash crop (Bond et al., 1985). Protein concentration is influenced by both genetic and environmental factors and inheritance of this trait is additive with some partial dominance (Bond et al., 1985).

\section{Materials and Methods}

The study was designed to work out the status of Genetic variability, divergence, character association and direct and indirect effects of these different traits on seed yield per plant among 18 faba bean genotypes at field experiment under present investigation was conducted during Rabi 2015-16 at the Student's Instructional Farm, N. D. University of Agriculture and Technology, Narendra Nagar (Kumarganj), Faizabad (U.P.) India. The experimental materials of studies comprised of 18 Faba bean genotypes including two check varieties viz., Vikrant and PRT-7. The experiment was laid out in Randomized Block Design. The observation were recorded on eleven traits viz., namely days to $50 \%$ flowering, days to maturity, plant height $(\mathrm{cm})$, number of branches per plant, number of pods per plant, number of seeds per pods, 100-seed weight (g), biological yield per plant $(\mathrm{g})$, protein content $(\%)$, harvest index $(\%)$ and seed yield per plant $(\mathrm{g})$.

\section{Analysis of variance}

The analysis of variance for Randomized Complete Block Design was carried out following Panse and Sukhatme (1967).

The ANOVA is simply a randomized block ANOVA on the check means. The entries in the ANOVA table were computed as follows:

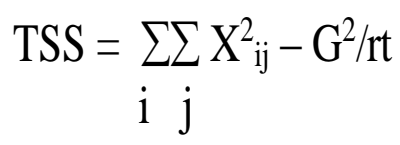


$\mathrm{SSR}=(1 / \mathrm{t}) \sum \mathrm{R}^{2}{ }_{\mathrm{j}}-\mathrm{G}^{2} / \mathrm{rt}$

$$
\begin{aligned}
\mathrm{SST} & =(1 / \mathrm{r}) \sum^{\mathrm{j}} \mathrm{T}^{2}{ }_{\mathrm{j}}-\mathrm{G}^{2} / \mathrm{rt} \\
\mathrm{i} & \\
\mathrm{SSE} & =\mathrm{TSS}-\mathrm{SSR}-\mathrm{SST} \\
\mathrm{MSE} & =\mathrm{SSE} /(\mathrm{r}-1)(\mathrm{t}-1)
\end{aligned}
$$

\section{Estimation of variability}

Variability for different characters was estimated as suggested by Burton and de Vane (1953). The formulae used in the estimation of coefficients of variability at genotypic (GCV), and phenotypic (PCV) levels are as follows:

$$
\begin{aligned}
& \mathrm{GCV}=\frac{\text { Genotypic } \quad \text { standard } \quad \text { deviation }}{\text { Mean }} \times 100
\end{aligned}
$$

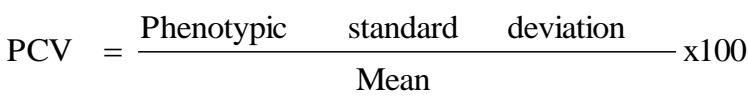

\section{Estimation of heritability}

Heritability in broad sense $\left(\mathrm{h}^{2}\right)$ was calculated using the formula suggested by Burton and de Vane (1953).

$$
\mathrm{h}^{2}=\frac{\sigma^{2} \mathrm{~g}}{\sigma^{2} \mathrm{~g}+\sigma^{2} \mathrm{e}}
$$

$\sigma^{2} \mathrm{~g}=$ genotypic variance.

$\sigma^{2} \mathrm{e}=$ environmental variance.

\section{Genetic advance as percent of mean ( $\overline{\mathrm{Ga}}$ )}

Expected genetic advance ( $\overline{\mathrm{Ga}}$ ) was estimated by the method suggested by Johnson et al., (1955).

$$
\begin{aligned}
& \text { GA }=\frac{\sigma^{2} g}{\sigma^{2} p} \times K \times \sigma p \\
& \frac{\sigma^{2} g}{\sigma p} \times K
\end{aligned}
$$

Where,

$\mathrm{K}=$ Selection differential at $5 \%$ Selection intensity i.e. 2.06

Genetic advance in per cent of Mean

$(\overline{\mathrm{Ga}}) \%=\frac{\text { Genetic } \text { advance }}{\overline{\mathrm{X}}} \times 100$

\section{Genetic divergence analysis:}

The genetic divergence among 26 genotypes of faba bean was worked out using Mahalanobis's $D^{2}$ statistics (Rao, 1952). The steps of the analysis are as follows:

A set of uncorrelated linear combination (Y's) was obtained by the pivotal condensation of the common dispersion matrix (Rao, 1952) of a set of correlated variables (X's).

Using the relationship between Y's and X's, the mean values of different genotypes for different characters $\left(\mathrm{X}_{1}\right.$ to $\left.\mathrm{X}_{10}\right)$ were transformed in to the mean values of set of uncorrelated linear combinations $\left(\mathrm{Y}_{1}\right.$ to $\left.\mathrm{Y}_{10}\right)$.

The $\mathrm{D}^{2}$ between $\mathrm{i}^{\text {th }}$ and $\mathrm{j}^{\text {th }}$ genotypes for $\mathrm{K}$ characters was calculated as:

$\mathrm{K}$

$\mathrm{D}_{\mathrm{ij}}^{2}=\sum\left(\mathrm{Y}_{\mathrm{it}}-\mathrm{Y}_{\mathrm{jt}}\right)^{2}$

$\mathrm{t}=1$

\section{Where, $\mathrm{t}=1$}

The K components was calculated separately and added to get $\mathrm{D}_{\mathrm{ij}}^{2}$

The $\mathrm{K}$ component of $\mathrm{D}^{2}{ }_{\mathrm{ij}}$ for each combination was ranked in descending order of magnitude.

These ranks were added up for each component over all the combinations of $i^{\text {th }}$ and $\mathrm{j}^{\text {th }}$, and the rank totals were obtained. 
Testing $\mathrm{D}^{2}{ }_{\mathrm{ij}}$ as the generalized statistical distance between $i^{\text {th }}$ and $j^{\text {th }}$ population, the population was grouped into number of clusters on the basis of $\mathrm{D}^{2}$ values. Any two genotypes belonging to the same cluster had the smallest cluster distance. On an average intra-cluster distance was less than intercluster distance (Tocher's method).

The seed yield was assumed to be dependent variable (effect), which is influenced by all the ten characters, the independent variable (cause) directly as well as indirectly through other characters. The variation in seed yield unexplained by the ten causes was presumed to be contributed by a residual factor (x), which is uncorrelated with other factors.

\section{Results and Discussion}

The analysis of variance for the Randomized Block Design, accommodating 18 faba bean accessions and one check, was done for each of the eleven characters. The Analysis of variance is presented in Table 1 . The analysis of variance revealed that mean squares due to treatments were highly significant.

The mean of 18 entries along with check mean and range for eleven characters are presented in Table 2. The days to $50 \%$ flowering ranged from 54.33 (DFB 14-1) to 61days (HB-45) with a mean of 58.18. The days to maturity ranged from 122.33 (Vikrant) to 130.00 (NDFB-15) with a mean of 125.68. The mean performance of plant height was 98.19 and it ranged from $92.14 \mathrm{~cm}$ (HB 9-15) to $104.21 \mathrm{~cm}$ (NDFB 15-1). The minimum number of branches per plant was exhibited by HB 11-12 (2.13), whereas, PRT-7(3.00) possessed highest number of branches per plant. The mean performance was 2.62.The lowest number of pods per plant was observed in case of HB-27 (19.33), while the highest value was recorded in HB 9-6 (25.46) with a mean of 21.88. The highest number of seeds per pod was exhibited by the entry HB 11-30 (3.13) exhibited lowest mean performance, while DFB 14-1(4.00) produced highest mean performance for this trait. The mean of pods per plant was 3.50.The 100-seed weight varied from $25.74 \mathrm{~g}$ in case of $\mathrm{HB} 9-6$ to $29.77 \mathrm{~g}$ in case of NDFB-14 and mean performance was $27.60 \mathrm{~g}$. The lowest and highest performance for biological yield per plant was recorded for HB-45(43.00g) and PRT-7 (60.03g), respectively with a mean performance of $51.40 \mathrm{~g}$. The lowest protein content was observed in case of HB 11-30 (24.43\%), while the highest value was recorded by the HB 8-12 $(26.76 \%)$. The Protein content showed a mean performance of 25.46 .

The harvest index varied from 30.73 per cent in case of PRT-7 to 39.67 per cent in HB 1115 and the mean performance was 36.39 per cent. The highest seed yield per plant was produced by HB 11-38 (20.59g), while the lowest seed yield per plant was observed in HB-45(14.64g). The mean performance of seed yield per plant was $18.62 \mathrm{~g}$.

The phenotypic and genotypic coefficient of variation for all the 11 characters has been given in Table 2. In general, the magnitude of phenotypic coefficient of variation was higher than genotypic coefficient of variation for all the characters. The characters which exhibited moderate estimates 10-20\% of PCV and GCV were plant height, and biological yield per plant. The remaining characters viz., days to $50 \%$ flowering, days to maturity, number of branches per plant, number of pods per plant, number of seeds per pod, 100-seed weight, protein content, seed yield per plant showed low estimates $(<10 \%)$ of PCV and GCV.

Heritability and genetic advance in per cent of mean were estimated for all the 11 characters (Table 2). High estimates of broad sense heritability $(>75 \%)$ were recorded for protein content $(82.8 \%)$ and 100 -seed weight $(81.7 \%)$. 
Table.1 Analysis of variance for eleven characters in Faba bean (Vicia faba L.)

\begin{tabular}{|c|c|c|c|c|}
\hline \multirow[t]{3}{*}{ S. No. } & \multirow[t]{2}{*}{ Characters } & \multicolumn{3}{|c|}{ Source of variation } \\
\hline & & Replication & Treatments & Error \\
\hline & Degree of freedom & 2 & 17 & 34 \\
\hline 1 & Days to $50 \%$ flowering & 1.407 & $17.185^{* *}$ & 1.740 \\
\hline 2 & Days to maturity & 5.851 & $17.783 * *$ & 5.753 \\
\hline 3 & Plant height $(\mathrm{cm})$ & 2.665 & $27.410 * *$ & 8.620 \\
\hline 4 & Number of branches / plant & 0.077 & $0.221 * *$ & 0.047 \\
\hline 5 & Number of pods / plant & 5.383 & $9.480 * *$ & 1.950 \\
\hline 6 & Number of seeds / pod & 0.001 & $0.158 * *$ & 0.034 \\
\hline 7 & 100-seed weight (g) & 0.664 & $5.327 * *$ & 0.369 \\
\hline 8 & Biological yield / plant (g) & 25.600 & $47.021 * *$ & 11.548 \\
\hline 9 & Protein content (\%) & 0.141 & $1.794 * *$ & 0.116 \\
\hline 10 & Harvest index (\%) & 1.533 & $15.619 * *$ & 5.625 \\
\hline 11 & Seed yield / plant(g) & 3.749 & $6.015^{* *}$ & 2.182 \\
\hline
\end{tabular}

** Significant at $1 \%$ probability level.

Table.2 Estimation of coefficient of variation, $\mathrm{h}^{2}$ (broad sense) and genetic advance in per cent of mean in Faba bean (Vicia faba L.)

\begin{tabular}{|c|c|c|c|c|c|c|c|c|}
\hline \multirow[t]{2}{*}{ Characters } & \multicolumn{2}{|c|}{ Range } & \multirow{2}{*}{$\begin{array}{l}\text { Grand } \\
\text { Mean }\end{array}$} & \multicolumn{2}{|c|}{ Coefficient of variation } & \multirow{2}{*}{$\begin{array}{l}\text { Heritability } \\
\text { in broad } \\
\text { sense }(\%)\end{array}$} & \multirow{2}{*}{$\begin{array}{l}\text { Genetic } \\
\text { advance }\end{array}$} & \multirow{2}{*}{$\begin{array}{c}\text { Genetic } \\
\text { advance in \% } \\
\text { of mean }\end{array}$} \\
\hline & Minimum & Maximum & & $\operatorname{PCV}(\%)$ & $\operatorname{GCV}(\%)$ & & & \\
\hline Days to $50 \%$ flowering & 54.33 & 61.00 & 58.18 & 6.89 & 5.15 & 74.70 & 4.04 & 6.94 \\
\hline Days to maturity & 122.33 & 130.00 & 125.69 & 9.76 & 4.00 & 41.10 & 2.64 & 2.10 \\
\hline Plant height (cm) & 91.14 & 104.21 & 98.19 & 14.88 & 6.26 & 42.10 & 3.34 & 3.40 \\
\hline Number of branches/plant & 2.13 & 3.00 & 2.62 & 0.10 & 0.05 & 54.90 & 0.37 & 13.99 \\
\hline Number of pods/plant & 19.33 & 25.46 & 21.88 & 4.46 & 2.50 & 56.30 & 2.44 & 11.19 \\
\hline Number of seed/pod & 3.13 & 4.00 & 3.50 & 0.07 & 0.04 & 55.00 & 0.31 & 8.90 \\
\hline 100-seed weight(g) & 25.74 & 29.77 & 27.60 & 2.02 & 1.65 & 81.70 & 2.39 & 8.68 \\
\hline Biological yield (g) & $43 . .00$ & 60.03 & 51.40 & 23.37 & 11.82 & 50.60 & 5.03 & 9.80 \\
\hline Protein content (\%) & 24.43 & 26.77 & 25.46 & 0.68 & 0.56 & 82.80 & 1.40 & 5.50 \\
\hline Harvest index (\%) & 30.73 & 30.68 & 36.39 & 8.96 & 3.33 & 37.20 & 2.29 & 6.29 \\
\hline Seed yield/plant (g) & 14.65 & 20.59 & 18.62 & 3.46 & 1.28 & 36.92 & 1.41 & 7.59 \\
\hline
\end{tabular}


Table.3 Clustering pattern of eighteen Faba bean genotypes on the basis of non-hierarchical Euclidean cluster analysis

\begin{tabular}{|c|c|l|}
\hline Cluster Number & Number of genotypes & Genotypes \\
\hline I & 5 & NDFB 15-1, PRT-7@, HB 11-15, HB 11-12, HB 9-6 \\
\hline II & 2 & NDFB-13, DFB 14-1 \\
\hline III & 1 & HB-45 \\
\hline IV & 7 & HB 9-1, HB-27, NDFB-15, NDFB-14, HB 11-30, HB 11-32, vikrant C \\
\hline V & 3 & HB 11-38, HB 9-15, HB 8-12 \\
\hline
\end{tabular}

Table.4 Estimates of average intra and inter-cluster distances for the five clusters in Faba bean (Vicia faba L.)

\begin{tabular}{|c|c|c|c|c|c|}
\hline Clusters & $\mathbf{I}$ & II & III & IV & $\mathbf{V}$ \\
\hline I & 39.890 & 73.445 & 113.559 & 76.546 & 90.928 \\
\hline II & & 30.448 & 88.918 & 64.198 & 72.990 \\
\hline III & & & 0.000 & 96.835 & 163.387 \\
\hline IV & & & & 26.690 & 60.539 \\
\hline V & & & & & 53.694 \\
\hline
\end{tabular}

Bold figures indicate direct $\mathrm{D}^{2}$ effects.

Table.5 Cluster means for different characters in Faba bean (Vicia faba L.)

\begin{tabular}{|c|c|c|c|c|c|c|c|c|c|c|c|}
\hline $\begin{array}{c}\text { Cluster } \\
\text { no. }\end{array}$ & $\begin{array}{c}\text { Days to } \\
50 \% \\
\text { flowering }\end{array}$ & $\begin{array}{l}\text { Days to } \\
\text { maturity }\end{array}$ & $\begin{array}{c}\text { Plant } \\
\text { height } \\
(\mathbf{c m})\end{array}$ & $\begin{array}{c}\text { Number } \\
\text { of } \\
\text { branches/ } \\
\text { plant }\end{array}$ & $\begin{array}{c}\text { Number } \\
\text { of pods/ } \\
\text { plant }\end{array}$ & $\begin{array}{c}\text { Number } \\
\text { of } \\
\text { seed/pod }\end{array}$ & $\begin{array}{c}\text { 100- } \\
\text { Seed } \\
\text { weight } \\
(\mathrm{g})\end{array}$ & $\begin{array}{c}\text { Biological } \\
\text { yield/plant } \\
\text { (g) }\end{array}$ & $\begin{array}{l}\text { Protein } \\
\text { content } \\
(\%)\end{array}$ & $\begin{array}{c}\text { Harvest } \\
\text { index } \\
(\%)\end{array}$ & $\begin{array}{c}\text { Seed } \\
\text { yield/ } \\
\text { plant (g) }\end{array}$ \\
\hline I & 58.133 & $127.533^{* *}$ & $99.901 * *$ & 2.600 & 22.187 & $3.440 *$ & $26.338 *$ & $54.122 * *$ & 24.753 & 34.809 & 18.674 \\
\hline II & $54.667 *$ & 124.333 & 97.030 & $2.833^{* *}$ & 22.750 & 3.700 & 27.107 & 50.022 & 24.950 & $37.133^{* *}$ & 18.557 \\
\hline III & $61.000 * *$ & $123.333 *$ & 95.863 & $2.400 *$ & $20.400 *$ & $3.867 * *$ & $29.477 * *$ & $43.000 *$ & $24.533^{*}$ & $34.417^{*}$ & $14.647 *$ \\
\hline IV & 59.238 & 125.667 & 99.042 & 2.695 & 20.845 & 3.448 & 28.763 & 50.299 & 25.786 & 37.269 & 18.664 \\
\hline $\mathbf{V}$ & 57.222 & 124.333 & $94.923 *$ & 2.422 & $23.711 * *$ & 3.467 & 26.694 & 53.177 & $26.578 * *$ & 37.186 & $19.846^{* *}$ \\
\hline
\end{tabular}


Table.6 Contribution of eleven characters of Faba bean (Vicia faba L.) towards divergence

\begin{tabular}{|c|l|c|c|}
\hline S.N. & \multicolumn{1}{|c|}{ Source } & Times Ranked 1st & Contribution \\
\hline $\mathbf{1}$ & Days to 50\% Flowering & 11.11 & $17 \%$ \\
\hline $\mathbf{2}$ & Days to Maturity & 2.61 & $4 \%$ \\
\hline $\mathbf{3}$ & Plant Height(cm) & 2.61 & $4 \%$ \\
\hline $\mathbf{4}$ & Number of branches/plant & 0.65 & $1 \%$ \\
\hline $\mathbf{5}$ & Number of pods/ Plant & 1.96 & $3 \%$ \\
\hline $\mathbf{6}$ & Number of seed /pod & 12.42 & $19 \%$ \\
\hline $\mathbf{7}$ & 100-Seed weight (g) & 28.10 & $43 \%$ \\
\hline $\mathbf{8}$ & Biological yield (g) & 6.54 & $10 \%$ \\
\hline $\mathbf{9}$ & Protein content (\%) & 28.76 & $44 \%$ \\
\hline $\mathbf{1 0}$ & Harvest index (\%) & 4.58 & $7 \%$ \\
\hline $\mathbf{1 1}$ & Seed yield/ Plant & 0.65 & $1 \%$ \\
\hline
\end{tabular}

Table.7 The most desirable genotypes identified for high mean performance for 11 characters in faba bean

\begin{tabular}{|c|l|l|}
\hline S. N. & Characters & Genotypes \\
\hline 1 & Days to 50\% flowering & NDFB-15, HB 11-12, HB 11-15, HB 9-6, HB 9-15, HB 8-12 DFB 14-1 \\
\hline 2 & Days to maturity & HB 11-15, HB 11-30, HB 9-15, HB-45, NDFB-13 \\
\hline 3 & Plant height (cm) & HB 11-32, HB 9-15, HB-27, HB-45, NDFB-13, DFB 14-1, PRT-7 \\
\hline 4 & Number of branches per plant & NDFB 15-1, HB 11-15, HB 11-30, HB 11-32, HB-27, NDFB-13, DFB 145-1 \\
\hline 5 & Number of pods per plant & HB 11-15, HB 11-32, HB 9-6, HB 9-15, NDFB-13, NDFB-14 \\
\hline 6 & Number of seed per pod & HB-27, NDFB-14, DFB 14-1, NDFB 15-1 \\
\hline 7 & 100-seed weight(g) & NDFB-15, HB 11-15, HB 11-30, HB-27, NDFB-14, DFB 14-1 \\
\hline $\mathbf{8}$ & Biological yield per plant (g) & NDFB 15-1, HB 11-12, HB 11-32, HB 9-6, \\
\hline 9 & Protein content $(\%)$ & NDFB-15, HB 11-15, HB 11-30, HB 11-32, HB 9-15, HB-27, HB 8-12, \\
\hline 10 & Harvest index (\%) & NDFB-15, HB 11-15, HB 11-32, HB-27, NDFB-13, NDFB-14, DFB 14-1 \\
\hline 11 & Seed yield per plant (g) & NDFB 15-1, HB 11-12, HB 11-15, HB 11-30, HB 11-32, DFB 14-1 \\
\hline
\end{tabular}




\section{Analysis of variance}

\begin{tabular}{|l|l|l|l|}
\hline Source of variation & d.f. & S.S. & M.S. \\
\hline Replications & $(\mathrm{r}-1)$ & SSR & MSR \\
\hline Treatments & $(\mathrm{t}-1)$ & SST & MST \\
\hline Error & $(\mathrm{r}-1)(\mathrm{t}-1)$ & SSE & MSE \\
\hline Total & $(\mathrm{rt}-1)$ & TSS & - \\
\hline
\end{tabular}

The moderate estimates of heritability (50$75 \%$ ) were observed for days to $50 \%$ flowering $(74.7 \%)$, number of pods per plant (56.3\%), number of branches per plant (54.9\%), biological yield per plant (50.6\%), while the low estimates of broad sense heritability were shown by plant height $(42.1 \%)$, days to maturity $(41.1 \%)$, harvest index (37.2) and seed yield per plant (36.2\%).

The high estimates of genetic advance in per cent of mean $(>10 \%)$ were recorded for number of branches per plant $(13.99 \%)$ and number of pods per plant (11.19\%). Biological yield $(9.80 \%)$, number of seed per pods $(8.9 \%)$ and 100 -seed weight $(8.68 \%)$ showed moderate estimate for genetic advance in per cent of mean, while the seed yield per plant (7.59\%), days to $50 \%$ flowering (6.94\%), harvest index (6.29\%), protein content $(5.50 \%)$, plant height $(3.40 \%)$ and days to maturity (2.10\%) showed > 75 high genetic advance in per cent of mean (Table 2).

The Mahalanobis- $\mathrm{D}^{2}$ analysis was employed to study genetic diversity existing among 18 faba bean entries on the basis of 11 quantitative characters. The pseudo F-test revealed that five clusters arrangement was the most appropriate for grouping the 18 entries. Therefore, the 18 entries were grouped into five different non-overlapping clusters. The distribution of 18 faba bean lines in five clusters is presented in Table 3. The highest number of genotypes appeared in cluster IV which contained 7 genotypes followed by cluster I having 5 genotypes.
Clusters V, cluster II, and cluster III were having 3, 2 and 1 genotypes respectively.

The intra and inter-cluster distance presented in Table 4. The highest intra-cluster distance was recorded in cluster V (53.694) followed by cluster I (39.890), cluster II (30.448) and cluster IV (26.690) while the lowest value was recorded in case of cluster III (0.00). The maximum inter cluster distance was recorded between cluster IV and cluster VI (76.08) followed by cluster II and cluster IV (46.05). The minimum inter cluster distance was observed between cluster III and cluster V (10.20) followed by cluster I and cluster III (15.16).

The mean performance of clusters, for eleven characters is presented in Table 5. The cluster I showed high mean performance for days to maturity (127.533) while it exhibited average mean performance for remaining characters. The cluster II had the genotypes having high mean performance for days to maturity (124.333), plant height (97.030), days to 50\% flowering (54.667) and biological yield per plant (50.022) and number of branches per plant (2.833) showed low mean performance, while other character showed average mean performance. The cluster III showed high mean performance for days to maturity (123.333) and showed low mean performance for number of branches/plant (2.400). The other characters showed average mean performance in cluster III. The cluster IV showed high mean performance for days to maturity (125.667) while it showed low mean performance for number of branches/plant 
(2.695) and average performance for other characters. The clusters V showed high mean performance for days to maturity (124.333) while low mean performance for number of branches/plant (2.422). The remaining characters showed average mean performance in cluster $\mathrm{V}$. The crosses between genotypes belonging to the cluster separated by low inter cluster distances are unlikely to generate promising recombinants in segregating generations (Patel et al., 2006, Gumber et al., 2006, Jeena et al., 2005, Durga et al., 2005 Raval and Dobariya 2004).

The contribution of eleven characters towards divergence (Table 6) showed the highest contribution by protein content $(44 \%), 100$ seed weight $(43 \%)$, number of seed per pod (19\%), days to $50 \%$ flowering $(17 \%)$ and biological yield (10\%). The number of branches per plant and seed yield per plant showed lowest contribution that is $1 \%$ towards divergence. The need of parental diversity in optimum magnitude to obtain superior genotypes for recovery of transgressive segregants has also been repeatedly emphasized (Griffing and Lindstrom 1954, Weinhues 1960, Moll and Robinson 1962 and Arunachalam 1988).

The data on ten quantitative characters from the experiment were utilized for estimation of mean, range, coefficient of variability. Nonhierarchical Euclidean cluster analysis was employed for the study of genetic diversity in germplasm.

The salient findings of the study and conclusion drawn from them are summarized below: 1. A wide range of variation for different characters and comparison of means of germplasm lines using least significant differences, indicated existence of very high degree of variability for all the characters in the germplasm collection. 2. The most promising lines showing highest seed yield with high mean performance for other yield contributing characters were identified as HB 11-38, HB 9-6, DFB 14-1, NDFB-14, HB 812 and DFB 14-1. The above mentioned genotypes also showed high mean performance for several other yield components. 3. The most desirable genotypes for characters other than seed yield were DFB 14-1 was found to be present in lowest mean performance for days to $50 \%$ flowering; $\mathrm{HB}$ 9-15 for days to maturity and HB 9-15 for plant height. 4. The genotype HB 11-30 had highest mean performance for number of branches per plant; HB 9-6 for number of pods per plant; HB-11-38 for biological yield per plant; HB 11-30 for harvest index; NDFB14 for 100- seed weight and HB 8-12 for protein content. The superior lines identified for seed yield and other characters may be used as donor parents in hybridization programme for the characters to which they showed high mean performance. 5. The nonhierarchical Euclidean cluster analysis grouped 18 genotypes in to five clusters. This indicated existence of high degree of genetic diversity in the germplasm evaluated in the present study. Therefore, these germplasm may serve as valuable source of selecting diverse parents for use in hybridization programme. 7. The highest number of genotypes appeared in cluster IV which contained 7 genotypes followed by cluster I, II and III having 5, 2 and 1 genotypes. 8. The five clusters in divergence analysis contained genotypes of heterogeneous origin, thereby indicating no parallelism between genetic and geographic diversity. Therefore, crosses between the members of clusters separated by high inter-cluster distance are likely to throw desirable sergeants. 9. In this context maximum inter cluster distance was recorded between cluster II and cluster V followed by cluster I and cluster $\mathrm{V}$ and cluster IV and cluster V. However, maximum intra-cluster distance was observed in cluster IV followed by cluster I. 10 . The different clusters showed 
considerable differences in intra-cluster group means of ten characters and genotypes having distinctly different mean performance for various characters were separated into different clusters. 11. Hence, the above diverse Faba bean genotypes may be exploited in hybridization programme to increase the production and productivity of this crop.

\section{Acknowledgements}

The authors are thankful to Dr. P.K. Singh, Professor and Head of the Department, Genetics and Plant Breeding, Narendra Deva University of Agriculture \& Technology, Kumarganj, Faizabad for providing research field and all essentials. In addition, the authors thank to Dhruv Chand Chaudhary and Urmila Devi for financial support andHamsa Poorna Prakash for supporting and editing this manuscript.

\section{References}

Anonymous 2015. Project Coordinator's Report (Rabi crops), AICRP on MULLaRP, IIPR, Kanpur.

Arunachalam V. 1981.Genetic divergence in plant breeding. Indian J. Genet.; 4(2):226-236.

Bond DA, Lawes DA, Hawtin GC, Saxena MC and Stephens JS. 1985 Faba Bean (Vicia faba L.).p 199-265. In: R.J. Summerfield and E.H. Roberts (eds.), Grain Legume Crops. William Collins Sons Co. Ltd. 8 Grafton Street, London, WIX 3LA, UK.

Burton. GW and de Vane EH. 1953. Estimating heritability in tall fescue from replicated clonal material. Agron. J. 45:478-481.

Darwin C 1859. The origin of species by means of natural selection or the preservation of favoured in the struggle for the life. Philosophical library, New York.

Dewey DR and Lu K H 1959 Correlation and path coefficient analysis of crested wheat grass seed production. Agron. J. 51:515-518.

Duke JA. 1981. Handbook of legumes of world economic importance. Plenum Press, New York. p. 199-265.

Durga KK, Rao Y K and Reddy M V 2005. Genetic divergence in chickpea (Cicer arietinum L.). Legume Res.; 28(4):250255.

FAO (2009). FAO statistical data base on agriculture http. // apps. Fao, 191-208.

Griffing B and Lindstrom EW 1954.A study of the combining ability of corn hybrids having varying proportions of cornbelt and non-corn belt germplasm. Agron. J. 46: 545-552.

Gumber RK, Singh S, Rathore P, Singh K and Verma, PK. 2006. Multivariate analysis over environments of multiple disease resistant lines of chickpea.Legume Res.; 29(1): 48-52.

Jeena, AS, Arora PP and Upreti MC. 2005. Divergence analysis in chickpea. Legume Res.; 28(2): 152-154.

Johnson R W, Robinson HF and Combstock $\mathrm{R}$ E 1955. Estimate of genetic and genetic variation and environmental variability in soyabean. Agron. J., 47: 314-318.

Lawes DA. 1980. Recent developments in understanding, improvement and use of Vicia faba. p. 625-636. In: R.J. Summerfield and A.H. Bunting (eds.), Advances in Legumes Science. Proceedings of the International Legume Conference, Kew, 31 July-4 August 1978, Royal Botanic Garden, Kew, the Missouri Botanical Garden, and the University of Reading, UK.

Mahalanobis, P.C. (1936). A statistical study at Chinese head measurements. J. Asiatic Soc. Bengal. 25: 301-377. 
Moll RH.and Robinson RF. 1962. Heterosis and Genetic diversity in varieties crosses of maize. Crop Sci. 2: 197-209.

Panse, V.G. and Sukhatme, P.V. (1978).Statistical methods for Agricultural workers, IIIrd edition, ICAR, New Delhi, 228-231.

Patel, S.; Babbar, A. and Rao, S.K. (2006). Genetic divergence in Kabuli chickpea.Indian J. Pulses Res., 19 (1): 107-108.
Rao, C.R. (1952). Advanced Statistical Methods in Biometrical Research. John Wiley and Sons, Inc., New York, pp. 357-363. Res., 18(2): 161-163.

Raval, L.J. and Dobariya, K.L. (2004). Assessment of genetic divergence in chickpea (Cicer arietinum L.).Annals of Agricultural Res., 25 (1): 30-34.

Weinhues F. 1960. Botany and breeding of wheat In: Progressive wheat production. Centre a Etude dela Azote, Gueneva.

\section{How to cite this article:}

Amit Kumar Chaudhary, C. B. Yadav, Hamsa Poorna Prakash, Shiv Prakash Shrivastav and Suraj Kumar Hitaishi. 2018. Genetic Variability, Heritability, Genetic Advance and Divergence for Yield and Its Contributing Traits in Faba bean (Vicia faba L.). Int.J.Curr.Microbiol.App.Sci. 7(06): 1897-1907. doi: https://doi.org/10.20546/ijcmas.2018.706.225 